\title{
Growth Retardants Affect Growth and Flowering of Scaevola
}

\author{
Terri W. Starman ${ }^{1}$ and Millie S. Williams ${ }^{2}$ \\ Department of Ornamental Horticulture and Landscape Design, Institute of \\ Agriculture, University of Tennessee, Knoxville, TN 37901-1071
}

Additional index words. fan flower, specialty floral crops, Scaevola aemula, S. albida, S. striata

Abstract. The effects of concentration and method of application of uniconazole on growth and flowering of Scaevola aemula R. Br. 'New Wonder', 'Mini Pink Fan', 'Purple Fan', and 'Royal Fan', Scaevola albida (Sm.) Druce. 'White Fan', and Scaevola striata 'Colonial Fan' were studied, as was the efficacy of four other growth retardants on S. aemula 'New Wonder'. Variables measured included plant width, flower stem number, flower stem length, flower number per stem, flower number per $\mathrm{cm}$ stem length, and days to flower. Uniconazole $\left(1.0 \mathrm{mg} \cdot \mathrm{L}^{-1}\right)$ applied as a medium drench to $S$. aemula 'New Wonder' reduced plant width and flower stem length without affecting flower stem number or time to flower. Flower number per stem and number of flowers per $\mathrm{cm}$ of stem length were increased, resulting in attractive, compact clusters of flowers. Paclobutrazol medium drench at 4.0 $\mathrm{mg} \cdot \mathrm{L}^{-1}$ gave similar results. Daminozide and ethephon sprays reduced plant width; however, flower number was reduced and ethephon delayed flowering. Ancymidol did not affect the parameters measured. When uniconazole drenches were applied to the other cultivars, plant width and flower stem length in all cultivars except 'White Fan' decreased as rate increased. Spray applications reduced plant width of all cultivars except 'Mini Pink Fan'. Flower stem length was not affected in any cultivar. Flowering habit was improved more in S. aemula 'New Wonder', 'Purple Fan', and 'Royal Fan' than in the other cultivars. Chemical names used: $\alpha$-cyclopropyl- $\alpha-(4-m e t h o x y p h e n y l)-5-$ pyrimidinemethanol (ancymidol); butanedioic acid mono (2,2-dimethylhydrazide) (daminozide); (2-chloroethyl)phosphonic acid (ethephon); B-[(4-chlorophenyl)methyl]$\alpha$-(1,1-dimethylethyl)-1H-1,2,4-triazole-1-ethanol (paclobutrazol); (E)-(s)-1-(4chlorophenyl)-4,4-dimethy-2-(1,2,4-triazol-1-yl)-pent-1-ene-3-ol (uniconazole).

The fan flower (S. aemula 'New Wonder') is a well-known vegetatively propagated annual in the United States. The genus contains 71 species in Australia and another 20 or so in tropical areas of the Indo-Pacific region (Armitage, 1997). There exists a wide diversity of growth habits and flower colors, including blue, violet, pink, and white. 'Royal Fan' is another blue-flowered cultivar with a more upright growth habit than 'New Wonder'. Scaevola striata has more rounded flowers and includes the cultivar 'Outback Colonial Fan'. Scaevola albida 'Outback White Fan' is a white-flowered low, spreading cultivar. $S$. aemula was taken from the wild in western Australia and improved by the Keintzler breeders of Germany and called 'Blue Wonder' (Armitage, 1997). 'Blue Wonder' has larger flowers and fewer disease problems than its wild predecessor. A later improvement, 'New

Received for publication 14 Sept. 1998. Accepted for publication 18 Dec. 1998. Research done at the Knoxville Agriculture Experiment Station, Univ. of Tennessee, Knoxville. Use of trade names does not imply endorsement of the products named nor criticism of similar ones not named. We thank Dr. Arnold Saxton for statistical analysis. The cost of publishing this paper was defrayed in part by the payment of page charges. Under postal regulations, this paper therefore must be hereby marked advertisement solely to indicate this fact.

${ }^{1}$ Associate Professor.

${ }^{2}$ Former Graduate Research Assistant.
Wonder', is a more profuse bloomer with larger flowers, and has become a popular cultivar for bedding plants and hanging baskets.

Growth retardants are often applied during production of hanging basket plants to prevent overgrowth that increases labor in pruning or otherwise makes shipping difficult (Barrett, 1994). The decision to apply growth retardants to hanging baskets presents growers with several questions. Choosing the best chemical is a challenge because chemicals, including ancymidol and daminozide, are active on most crops and easy to apply but are less effective than are paclobutrazol and uniconazole. However, paclobutrazol and uniconazole require more precise spray procedures to prevent overdosing. Ethephon can delay flowering, and chlormequat may cause leaf yellowing. Media drench applications are often preferred over foliar spray application for hanging baskets because the baskets are hard to reach when grown overhead in the greenhouse and spray drift can affect the growth of other crops below (Barrett, 1994). Drenching has a longer period of activity than spray application, and therefore drenched plants can be held longer in the greenhouse (Barrett, 1994).

In an experiment to determine the number of vegetative plugs (one to three) of S. aemula 'New Wonder' and pinches (zero to three) necessary to produce a $24.5-\mathrm{cm}$ hanging basket, two or three pinches did not improve branching and delayed flowering (Starman and Faust, 1996). In a cultivar trial, 'Purple Fan' had a growth habit suitable for hanging basket production, whereas 'Royal Fan' was too tall and upright and 'Pink Fan', 'White Fan', and 'Colonial Fan' were too spindly for use alone in hanging baskets (Williams and Starman, 1997).

The authors observed that when S. aemula 'New Wonder' was grown outdoors in the summer, internodes between axillary flowers were short, giving the appearance that flowering was in round, spike-like inflorescences. However, during early spring greenhouse production, internodes were elongated and the appearance was less floriferous. When uniconazole was applied as a media drench at $1.0 \mathrm{mg} \cdot \mathrm{L}^{-1}$ to $S$. aemula 'New Wonder' in a preliminary experiment, internode length between axillary flowers was reduced, giving the appearance of being grown outdoors. The reduction in stem length caused flowers to appear as round, spike-like inflorescences at the end of the stems and the overall appearance was a more compact, more colorful, floriferous plant.

Our objectives were to determine the optimum concentration of uniconazole media drenches for growth control of S. aemula 'New Wonder', to determine if the growth and flowering habit of other cultivars of scaevola could be improved for container production with foliar sprays or medium drenches of uniconazole, and to ascertain the efficacy of other growth retardants on 'New Wonder'.

\section{Materials and Methods}

Plant culture. Rooted cuttings were received as vegetatively propagated, rooted plugs grown in $37-\mathrm{cm}^{3}$ containers. Plants were transplanted (one plug per pot) into a soilless medium (Pro-Mix BX, Premier Horticulture, Inc., Red Hill, Pa.) in 10-cm-diameter $\left(365 \mathrm{~m}^{3}\right)$ plastic containers. Plants were irrigated by hand and fertilized using Peter's water-soluble fertilizer 20 N-4.3 P-16.6 K (The Scotts Co., Marysville, Ohio). Fertilizer was applied at $200 \mathrm{mg} \cdot \mathrm{L}^{-1} \mathrm{~N}$ with each irrigation. Plants were grown in a $21^{\circ} / 18^{\circ} \mathrm{C}$ (venting/night temperature set points) glasshouse.

Plant growth regulatorapplication. Chemicals were applied when axillary branches were $\approx 5 \mathrm{~cm}$ in length. Amount of chemical was according to commercial recommendations, i.e., ancymidol, daminozide, and ethephon were sprayed to runoff; paclobutrazol and uniconazole were sprayed evenly at $204 \mathrm{~mL}$ per $1 \mathrm{~m}^{2}$ of bench space; drenches were applied at $120 \mathrm{~mL}$ per $10-\mathrm{cm}$ pot.

Expt 1. Uniconazole medium drench rates on S. aemula 'New Wonder'. Plants were pinched by the supplier (Pleasant View Gardens, Loudon, N.H.) prior to arrival in Mar. 1996 and potted on arrival. They were treated with uniconazole drenches 2 weeks after potting. There were five drench treatments $(0$, $0.5,1.0,2.5$, and $\left.5.0 \mathrm{mg} \cdot \mathrm{L}^{-1}\right)$ and eight replications (plants) per treatment.

Expt 2. Uniconazole medium drench and foliar spray application on scaevola species and cultivars. Rooted cuttings of $S$. striata 
'Colonial Fan', S. aemula 'Pink Fan', 'Purple Fan', 'Royal Fan', and S. albida 'White Fan' were received as vegetatively propagated rooted plugs from Takao Nursery, Fresno, Calif., in Dec. 1997. All plants had one dominant shoot that was pruned to the pot edge 2 weeks after planting. Treatments, applied 4 weeks after pruning, included uniconazole as a foliar spray at $0,5.0,10.0$, or $20.0 \mathrm{mg} \cdot \mathrm{L}^{-1}$ or as a medium drench at $0,0.5,1.0,2.5$, or 5.0 $\mathrm{mg} \cdot \mathrm{L}^{-1}$. There were seven plants per treatment.

Expt 3. Efficacy of plant growth retardants on S. aemula 'New Wonder'. Plants were received from Pleasant View Gardens and potted in May 1997. They were pinched to five nodes 2 weeks later. Five different chemicals were applied to six plants per treatment at varying foliar spray and/or medium drench rates $10 \mathrm{~d}$ after pinching. Treatments included ancymidol foliar spray at 66 or $132 \mathrm{mg} \cdot \mathrm{L}^{-1}$ or medium drench at 2 or $4 \mathrm{mg} \cdot \mathrm{L}^{-1}$, daminozide foliar spray at 2500 or $5000 \mathrm{mg} \cdot \mathrm{L}^{-1}$, ethephon foliar spray at 500 or $1000 \mathrm{mg} \cdot \mathrm{L}^{-1}$, paclobutrazol foliar spray at 40 or $80 \mathrm{mg} \cdot \mathrm{L}^{-1}$ or medium drench at 4 or $8 \mathrm{mg} \cdot \mathrm{L}^{-1}$, and uniconazole foliar spray at 10 or $20 \mathrm{mg} \cdot \mathrm{L}^{-1}$ or medium drench at 1 or $2 \mathrm{mg} \cdot \mathrm{L}^{-1}$.

Data collected. Plants were examined every other day until first open flower. Other data, including plant width, were collected when plants were considered marketable, i.e. foliage cascading from the container and flowering throughout the leaf canopy. Flower stem number was the sum of all stems with flowers. Flower stem length, flower number per stem, and flower number per $\mathrm{cm}$ were averages from three randomly selected stems per plant. Flower stem length was measured from the proximal to the distal flower, and flower number per $\mathrm{cm}$ was calculated. Fresh and dry weights were measured at harvest and after drying at $80^{\circ} \mathrm{C}$ for $72 \mathrm{~h}$. Completely randomized designs were used in all experiments. Data were analyzed by analysis of variance using a general linear model (SAS; SAS Institute, Cary, N.C.) and least significant difference was used for mean separation or orthogonal polynomial contrasts for the trend analysis.

\section{Results and Discussion}

As uniconazole medium drench rates applied to $S$. aemula 'New Wonder' increased from 0 to $5.0 \mathrm{mg} \cdot \mathrm{L}^{-1}$, plant width decreased (Fig. 1). The optimum drench rate was 1.0 $\mathrm{mg} \cdot \mathrm{L}^{-1}$. The $0.5 \mathrm{mg} \cdot \mathrm{L}^{-1}$ rate did not reduce plant width, and the 2.5 and $5.0 \mathrm{mg} \cdot \mathrm{L}^{-1}$ rates resulted in excessive growth reduction, coupled with some leaf curling and cupping. Fresh and dry weight (251 and $15 \mathrm{~g}$, respectively) were not affected by drench rate. Flowers per $\mathrm{cm}$ were not calculated in this experiment; however, the flowers appeared to be more closely spaced in round, spike-like inflorescences.

As uniconazole drench rate increased, plant width decreased for all scaevola cultivars except 'White Fan' (Table 1). Flower stem number was reduced when a uniconazole drench was applied to 'Colonial Fan', and decreased as drench rate increased for 'Mini Pink Fan' and 'Purple Fan'. Flower stem length declined

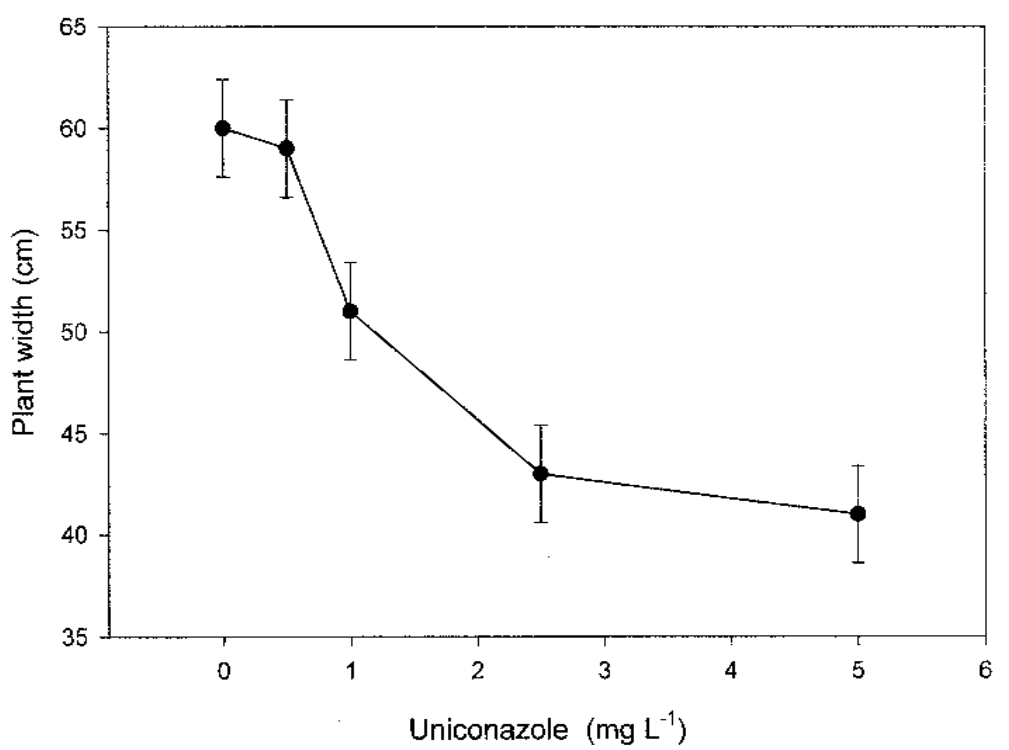

Fig 1. Effect of uniconazole medium drench on plant width of Scaevola aemula 'New Wonder'. Vertical bars represent standard error of the means (SE).

Table 1. Responses of five scaevola cultivars to media drenches of uniconazole.

\begin{tabular}{|c|c|c|c|c|c|c|c|}
\hline \multirow[b]{2}{*}{ Cultivar } & \multirow{2}{*}{$\begin{array}{c}\text { Uniconazole } \\
\left(\mathrm{mg} \cdot \mathrm{L}^{-1}\right)\end{array}$} & \multirow{2}{*}{$\begin{array}{l}\text { Plant } \\
\text { width } \\
(\mathrm{cm})\end{array}$} & \multicolumn{2}{|c|}{ Flower stem: } & \multicolumn{2}{|c|}{ Flower no: } & \multirow{2}{*}{$\begin{array}{l}\text { Days to } \\
\text { flower }\end{array}$} \\
\hline & & & No. & Length $(\mathrm{cm})$ & Per stem & Per $\mathrm{cm}$ & \\
\hline \multirow[t]{4}{*}{ Colonial Fan } & 0 & 56 & 6 & 10 & 5 & 0.51 & 83 \\
\hline & 1.0 & 55 & 4 & 7 & 5 & 0.65 & 84 \\
\hline & 2.5 & 52 & 4 & 10 & 7 & 0.77 & 85 \\
\hline & 5.0 & 43 & 4 & 5 & 5 & 0.97 & 89 \\
\hline Trend analysis & & $\mathrm{L}^{* *}$ & $\mathrm{~L}^{* *}, \mathrm{Q}^{*}$ & $\mathrm{~L}^{*}$ & NS & $\mathrm{L}^{* *}$ & NS \\
\hline \multirow[t]{4}{*}{ Mini Pink Fan } & 0 & 120 & 8 & 10 & 9 & 0.91 & 90 \\
\hline & 1.0 & 116 & 8 & 11 & 9 & 0.83 & 83 \\
\hline & 2.5 & 89 & 5 & 13 & 10 & 0.80 & 82 \\
\hline & 5.0 & 53 & 3 & 6 & 8 & 1.62 & 88 \\
\hline Trend analysis & & $\mathrm{L}^{* * * *}$ & $\mathrm{~L}^{* * * *}$ & $\mathrm{~L}^{*}, \mathrm{Q}^{*}$ & NS & $\mathrm{L}^{* * *}, \mathrm{Q}^{* *}$ & $\mathrm{Q}^{* *}$ \\
\hline \multirow[t]{4}{*}{ Purple Fan } & 0 & 65 & 12 & 7 & 10 & 1.5 & 70 \\
\hline & 1.0 & 34 & 11 & 4 & 12 & 3.3 & 68 \\
\hline & 2.5 & 24 & 7 & 3 & 13 & 4.4 & 74 \\
\hline & 5.0 & 21 & 6 & 2 & 10 & 4.8 & 76 \\
\hline Trend analysis & & $\mathrm{L}^{* * *}, \mathrm{Q}^{* * *}$ & $\mathrm{~L}^{* *}$ & $\mathrm{~L}^{* * *}, \mathrm{Q}^{* *}$ & NS & $\mathrm{L}^{* * *}, \mathrm{Q}^{* *}$ & NS \\
\hline \multirow[t]{4}{*}{ Royal Fan } & 0 & 73 & 6 & 12 & 10 & 0.87 & 77 \\
\hline & 1.0 & 55 & 5 & 9 & 9 & 1.1 & 76 \\
\hline & 2.5 & 44 & 6 & 7 & 13 & 2.4 & 73 \\
\hline & 5.0 & 29 & 5 & 4 & 12 & 4.0 & 79 \\
\hline Trend analysis & & $\mathrm{L}^{* * *}$ & NS & $\mathrm{L}^{* * *}$ & NS & $\mathrm{L}^{* * *}$ & NS \\
\hline \multirow[t]{4}{*}{ White Fan } & 0 & 135 & 8 & 10 & 9 & 0.93 & 102 \\
\hline & 1.0 & 144 & 7 & 12 & 11 & 0.88 & 97 \\
\hline & 2.5 & 134 & 8 & 12 & 11 & 0.95 & 93 \\
\hline & 5.0 & 115 & 6 & 12 & 10 & 0.93 & 102 \\
\hline Trend analysis & & NS & NS & NS & NS & NS & NS \\
\hline
\end{tabular}

$\mathrm{L}, \mathrm{Q}=$ Linear or quadratic, respectively.

ns, *,**,*** Nonsignificant or significant at $P \leq 0.05,0.01$, or 0.001 , respectively.

as uniconazole drench rate increased in all cultivars except 'White Fan'. The reduction in flower stem length without a reduction in flower number per stem resulted in an increase in flower number per $\mathrm{cm}$ for all cultivars but 'White Fan'. This increase in flower number per $\mathrm{cm}$ gave a visual effect of flowering in round clusters for 'Purple Fan' and 'Royal Fan' similar to that observed with $S$. aemula 'New Wonder'. The effect was not as noticeable on 'Mini Pink Fan', because individual flowers were small, or for 'Colonial Fan' because it was less floriferous naturally.
Uniconazole did not delay flowering in any cultivar.

Plant width decreased linearly for all cultivars except 'Mini Pink Fan' as uniconazole spray rate increased from 0 to $20 \mathrm{mg} \cdot \mathrm{L}^{-1}$ (Table 2). Flower stem number decreased linearly in 'Mini PinkFan' and 'White Fan' as uniconazole rate increased. Flower stem length, flower number per stem, and flower number per $\mathrm{cm}$ of the five cultivars tested were not affected by uniconazole sprays, but days to flower increased for 'Purple Fan' and 'Royal Fan' as spray rate increased. 
Plant width of $S$. aemula 'New Wonder' was decreased by all plant growth regulators except ancymidol, but only the higher foliar spray rates of daminozide and paclobutrazol reduced plant width (Table 3). Both foliar spray rates of ethephon and uniconazole and drench rates of paclobutrazol and uniconazole reduced plant width. In general, ancymidol foliar sprays or media drenches, daminozide foliar spray at $2500 \mathrm{mg} \cdot \mathrm{L}^{-1}$, paclobutrazol foliar sprays, and uniconazole foliar sprays did not affect most of the flowering variables measured for S. aemula 'New Wonder'.

Daminozide foliar spray at $5000 \mathrm{mg} \cdot \mathrm{L}^{-1}$ and ethephon at both of the rates applied reduced flower stem number. Flower stem length was reduced by ethephon foliar sprays or paclobutrazol and uniconazole drenches. Flower number per stem was reduced by daminozide and ethephon and increased with uniconazole drench at $1.0 \mathrm{mg} \cdot \mathrm{L}^{-1}$. Ethephon delayed flowering by 8 to $11 \mathrm{~d}$ and uniconazole sprays by $5 \mathrm{~d}$.

Paclobutrazol and uniconazole were the only two chemicals effective in increasing the flower number per $\mathrm{cm}$ of $S$. aemula New Wonder', and only when applied as a medium drench rather than as a foliar spray. Both paclobutrazol and uniconazole are triazoles and have similar chemical structures and modes of action (Davis et al., 1989). Triazole growth regulators are more active inhibitors of stem elongation than are other antigibberellins (ancymidol and daminozide) used in this study, and are generally more effective in retarding growth when applied to the soil or directly to stems than to the foliage (Barrett and Bartuska, 1882). With drench application, movement of the chemical is directly into the xylem to the vascular system behind the apex; the xylem is thought to act as a reservoir, maintaining a sufficiently high concentration of the growth inhibitor to reduce internode elongation (Davis et al., 1989). When applied to leaves, triazole growth regulators must be translocated through the phloem to the xylem, reducing their efficiency.

Uniconazole medium drench at $1.0 \mathrm{mg} \cdot \mathrm{L}^{-1}$ or paclobutrazol medium drench at $4 \mathrm{mg} \cdot \mathrm{L}^{-1}$ can be recommended to commercial flower growers to reduce plant width and flower stem length of S. aemula 'New Wonder' without reducing the numbers of flower stems or flowers per stem or delaying flowering. Flower number per $\mathrm{cm}$ would be increased, improving the appearance of flowering stems. These drench treatments would be particularly useful to commercial flower growers who produce $S$. aemula 'New Wonder' as 10-cm containers during early spring under low-light conditions. Further research is needed to determine optimum dosage and timing of application for hanging basket production and the persistence of treatment after sale.

Table 2. Responses of five scaevola cultivars to foliar sprays of uniconazole.

\begin{tabular}{|c|c|c|c|c|c|c|c|}
\hline \multirow[b]{2}{*}{ Cultivar } & \multirow{2}{*}{$\begin{array}{l}\text { Uniconazole } \\
\left(\mathrm{mg} \cdot \mathrm{L}^{-1}\right)\end{array}$} & \multirow{2}{*}{$\begin{array}{l}\text { Plant } \\
\text { width } \\
(\mathrm{cm})\end{array}$} & \multicolumn{2}{|c|}{ Flower stem: } & \multicolumn{2}{|c|}{ Flower no. } & \multirow{2}{*}{$\begin{array}{l}\text { Days to } \\
\text { flower }\end{array}$} \\
\hline & & & No. & Length $(\mathrm{cm})$ & per stem & per $\mathrm{cm}$ & \\
\hline \multirow[t]{4}{*}{ Colonial Fan } & 0 & 57 & 4 & 10 & 4 & 0.48 & 84 \\
\hline & 5 & 55 & 4 & 8 & 5 & 0.66 & 83 \\
\hline & 10 & 49 & 4 & 9 & 5 & 0.63 & 84 \\
\hline & 20 & 44 & 4 & 8 & 6 & 0.77 & 83 \\
\hline Trend analysis & & $\mathrm{L}^{* * *}$ & NS & NS & NS & NS & NS \\
\hline \multirow[t]{4}{*}{ Mini Pink Fan } & 0 & 110 & 11 & 11 & 9 & 0.90 & 83 \\
\hline & 5 & 103 & 11 & 10 & 9 & 0.97 & 82 \\
\hline & 10 & 100 & 10 & 11 & 10 & 0.91 & 86 \\
\hline & 20 & 100 & 7 & 11 & 9 & 0.86 & 88 \\
\hline Trend analysis & & NS & $\mathrm{L}^{* *}$ & NS & NS & NS & NS \\
\hline \multirow[t]{4}{*}{ Purple Fan } & 0 & 70 & 13 & 8 & 9 & 1.48 & 68 \\
\hline & 5 & 68 & 12 & 8 & 9 & 1.12 & 68 \\
\hline & 10 & 59 & 11 & 6 & 7 & 1.12 & 77 \\
\hline & 20 & 40 & 9 & 6 & 8 & 1.45 & 78 \\
\hline Trend analysis & & $\mathrm{L}^{* * *}$ & NS & NS & NS & NS & $\mathrm{L}^{* *}$ \\
\hline \multirow[t]{4}{*}{ Royal Fan } & 0 & 77 & 7 & 14 & 10 & 0.72 & 73 \\
\hline & 5 & 72 & 7 & 12 & 10 & 0.89 & 76 \\
\hline & 10 & 67 & 7 & 13 & 12 & 0.94 & 73 \\
\hline & 20 & 52 & 4 & 10 & 9 & 0.93 & 81 \\
\hline Trend analysis & & $\mathrm{L}^{* * *}$ & NS & NS & NS & NS & $\mathrm{L}^{*}$ \\
\hline \multirow[t]{4}{*}{ White Fan } & 0 & 135 & 7 & 10 & 8 & 0.82 & 101 \\
\hline & 5 & 129 & 9 & 11 & 11 & 1.03 & 98 \\
\hline & 10 & 130 & 6 & 11 & 9 & 0.86 & 101 \\
\hline & 20 & 114 & 5 & 10 & 9 & 0.93 & 102 \\
\hline Trend analysis & & $\mathrm{L}^{* * *}$ & $\mathrm{~L}^{*}$ & NS & NS & NS & NS \\
\hline
\end{tabular}

Ns, ${ }^{, * *},{ }^{* * *}$ Nonsignificant or significant at $P \leq 0.05,0.01$, or 0.001 , respectively. $\mathrm{L}=$ linear.

Table 3. Responses of Scaevola aemula 'New Wonder' to five chemical growth regulators applied as foliar sprays (FS) or medium drenches (MD)

\begin{tabular}{|c|c|c|c|c|c|c|c|c|}
\hline \multirow[b]{2}{*}{ Chemical } & \multirow{2}{*}{$\begin{array}{c}\text { Application } \\
\text { method }\end{array}$} & \multirow{2}{*}{$\begin{array}{c}\text { Rate } \\
\left(\mathrm{mg} \cdot \mathrm{L}^{-1}\right)\end{array}$} & \multirow{2}{*}{$\begin{array}{l}\text { Plant width } \\
\text { (cm) }\end{array}$} & \multicolumn{2}{|c|}{ Flower stem: } & \multicolumn{2}{|c|}{ Flower no: } & \multirow{2}{*}{$\begin{array}{l}\text { Days to } \\
\text { flower }\end{array}$} \\
\hline & & & & No. & $\overline{\text { Length }(\mathrm{cm})}$ & per stem & $\overline{\text { per } \mathrm{cm}}$ & \\
\hline \multirow[t]{2}{*}{ Control } & FS & 0 & 79 & 19 & 14 & 12 & 0.83 & 44 \\
\hline & MD & 0 & 79 & 16 & 17 & 12 & 0.76 & 44 \\
\hline \multirow[t]{4}{*}{ Ancymidol } & FS & 66 & 78 & 17 & 16 & 11 & 0.71 & 46 \\
\hline & & 132 & 75 & 17 & 14 & 11 & 0.83 & 45 \\
\hline & MD & 2 & 78 & 16 & 15 & 12 & 0.76 & 47 \\
\hline & & 4 & 72 & 15 & 16 & 12 & 0.78 & 45 \\
\hline \multirow[t]{3}{*}{ Daminozide } & FS & 2500 & 73 & 15 & 15 & 9 & 0.62 & 44 \\
\hline & & 5000 & 67 & 12 & 15 & 8 & 0.53 & 47 \\
\hline & MD & --- & --- & --- & --- & --- & --- & --- \\
\hline \multirow[t]{3}{*}{ Ethephon } & FS & 500 & 43 & 10 & 10 & 7 & 0.75 & 52 \\
\hline & & 1000 & 26 & 3 & 5 & 4 & 0.60 & 55 \\
\hline & MD & --- & --- & --- & --- & -- & --- & --- \\
\hline \multirow[t]{4}{*}{ Paclobutrazol } & FS & 40 & 73 & 17 & 16 & 11 & 0.73 & 46 \\
\hline & & 80 & 68 & 19 & 15 & 13 & 0.86 & 45 \\
\hline & MD & 4 & 46 & 17 & 8 & 12 & 1.70 & 47 \\
\hline & & 8 & 44 & 14 & 7 & 12 & 1.80 & 45 \\
\hline \multirow[t]{4}{*}{ Uniconazole } & FS & 10 & 65 & 17 & 15 & 11 & 0.78 & 49 \\
\hline & & 20 & 55 & 15 & 12 & 10 & 0.82 & 49 \\
\hline & MD & 1 & 56 & 17 & 11 & 15 & 1.40 & 46 \\
\hline & & 2 & 38 & 15 & 7 & 12 & 1.80 & 46 \\
\hline $\mathrm{LSD}_{0.05}$ & & & 9.1 & 4.1 & 2.6 & 2.1 & 0.22 & 3.8 \\
\hline
\end{tabular}

\section{Literature Cited}

Armitage, A. 1997. Scaevola: A well-traveled plant. Greenhouse Grower 15(4):61-62.

Barrett, J.E. 1994. Growth regulators, p. 43-46. In: Tips on growing and marketing hanging baskets. Ohio Florists' Assn., Columbus, Ohio.

Barrett, J.E. and C.A. Bartuska. 1982. PP333 effects on stem elongation dependent on site of applica- tion. HortScience 17:737-738.

Davis, T.D., G.L. Steffens, and N. Sankhla. 1989. Triazole plant growth regulators. Hort. Rev. 10:63-105

Starman, T.W. and J.E. Faust. 1996. Banking on new baskets. Greenhouse Grower 14(3):86, 88, 93.

Williams, M.S. and T.W. Starman. 1997. Create some consumer thunder with hanging plants from down under. GMPro 17(10):30-31. 